\title{
RNA, Ribosomal 1
}

National Cancer Institute

\section{Source}

National Cancer Institute. RNA, Ribosomal 1. NCI Thesaurus. Code C29875.

Encoded by human RNR1 Gene, RNA Ribosomal 1 is a ribosomal RNA associated with proteins as structural components of a ribosome where polypeptides are produced by interacting with tRNA and mRNA. (From $\mathrm{NCl}$ ) 